\title{
Changes in the Dendritic Geometry of Mouse Superior Cervical Ganglion Cells Following Postganglionic Axotomy
}

\author{
Hiromu Yawo \\ Department of Anatomy and Neurobiology, Washington University School of Medicine, St. Louis, Missouri 63110
}

\begin{abstract}
The dendritic geometry of mouse superior cervical ganglion cells was studied over periods of up to 3 months after postganglionic axotomy. Intracellular injection of HRP showed that total dendritic length and complexity were reduced by 60-70\%, on average, among cells whose postganglionic axons had been crushed 2 weeks before. Both parameters gradually recovered in parallel with ganglion cell reinnervation of the periphery. These results indicate that neuronal interactions with peripheral targets influence the configuration of ganglion cell dendrites throughout life. The implications of this conclusion are discussed.
\end{abstract}

Neurons in the mammalian nervous system vary widely in their dendritic geometry. The factors that control the number and complexity of these postsynaptic processes, both in development and thereafter, remain largely obscure. This issue is of particular importance because the geometry of postsynaptic cells appears to detcrminc the number of axons that inncrvate them, at least in the autonomic nervous system (Hume and Purves, 1981; Purves and Hume, 1981; Forehand and Purves, 1984; Purves and Lichtman, 1985). Three possible potential determinants of the extent and configuration of neuronal dendrites come to mind: (1) an intrinsic (genetic) influence, (2) an influence arising from innervation received, and (3) an influence arising from targets innervated. The purpose of the present study was to explore the last of these possibilities, namely, the influence of neuronal targets on dendritic morphology.

Several earlier observations have suggested that an interaction with peripheral targets is important for the maintenance of normal dendritic morphology (Cerf and Chacko, 1958; Sumner and Watson, 1971; Purves, 1975, 1976). However, no systematic study has been done on mammals using modern labeling techniques that demonstrate the detailed morphology of individual neurons. In particular, no study has been done with an intracellular label to quantify the extent and time course of the morphological changes that have been suggested as occurring after interruption of the connection between neurons and their targets. The present experiments were carried out in the superior

\footnotetext{
Received Feb. 2, 1987; revised May 15, 1987; accepted May 15, 1987.

This work was supported by a McDonnell Fellowship to H.Y. and by Grants NS 11699 and NS 18629 from the National Institutes of Health to Dale Purves. Computer morphometry was made possible by a Javits Center grant. I thank D. Purves for support and advice throughout this study, and C. Forehand, L. Harris, S. Pomeroy, W. Snider, and J. Voyvodic for useful comments on the manuscript. I also thank P. Newton for her excellent technical assistance.

Correspondence should be addressed to Hiromu Yawo at his present address: Department of Physiology, Kyoto University Faculty of Medicine, Kyoto, 606, Japan.

Copyright (C) 1987 Society for Neuroscience $0270-6474 / 87 / 113703-09 \$ 02.00 / 0$
}

cervical ganglion of the mouse using intracellular injection of IIRP to monitor the effects on dendritic morphology of interrupting the postganglionic axons. I also observed the dendritic arbors of these cells as their axons regenerated to the periphery. The results indicate that disconnection of ganglion cells from peripheral targets causes the dendrites to retract substantially over a period of about 2 weeks. Coincident with axonal regeneration to the periphery, the dendrites extend once again and approach their original length and complexity. The implication of these findings is that the retrograde trophic support known to influence several other aspects of these ganglion cells also affects neuronal geometry, and therefore the organization of preganglionic innervation.

A preliminary report of some of these results has been presented (Yawo, 1986).

\section{Materials and Methods}

Young adult mice (CF 1 strain, 25-30 gm; about 8-12 weeks old) were anesthetized with chloral hydrate $(0.6 \mathrm{gm} / \mathrm{kg})$ and the left superior cervical ganglion was identified, together with its central and peripheral connections. One of the major postganglionic nerves, the external carotid, was crushed twice with jeweler's forceps for $10 \mathrm{sec}$ at a point $0.5-$ $1.0 \mathrm{~mm}$ distal to the ganglion. The wound was then closed and the animals revived and returned to their cages.

After an interval of 1-12 weeks, the mice were anesthetized once again with an overdose of pentobarbital $(500 \mathrm{mg} / \mathrm{kg})$. Under deep anesthesia, they were perfused through the heart with oxygenated mammalian Ringer's solution to remove most of the blood. The left (operated) superior cervical ganglion was dissected free and placed in a recording chamber continuously superfused with oxygenated mammalian Ringer's solution. In some cases, the contralateral (right) ganglion was also examined. Sham-operated animals served as controls.

Individual neurons were impaled with triangular glass pipettes (American Glass Co.) filled with a $5 \%$ solution of HRP (Sigma type VI) in 0.2 $\mathrm{M}$ potassium acetate in Tris buffer $(0.05 \mathrm{M}$; $\mathrm{pH}$ 7.6) (Purves and Hume, 1981). The resistance of the microelectrodes ranged between 120 and $160 \mathrm{M} \Omega$. Neurons that had an action potential of at least $60 \mathrm{mV}$ in response to intracellular current injection were filled with HRP by iontophoresis: $5-10$ cells were injected in each ganglion (50 msec pulses of 3-6 nA depolarizing current at $5 \mathrm{~Hz}$ for 3-8 min). Most of the cells had resting potentials of $-40 \mathrm{mV}$ or more at the end of the injection period. One to two hours were allowed for the diffusion of HRP throughout the last cell that was injected; the ganglion was then fixed overnight in $1.25 \%$ glutaraldehyde and $0.5 \%$ paraformaldehyde. The following day, the HRP reaction product was developed by the method of Hanker et al. (1977). Ganglia were subsequently dehydrated, cleared, and mounted whole on slides with DPX (BDH Chemicals, Ltd.).

Only well-stained cells whose axons could be followed for at least 300 $\mu \mathrm{m}$ from the cell bodies were included in the study. In experimental ganglia, neurons whose axons could be traced into the crushed nerve were considered to have been axotomized; neurons whose axons could not be followed into the external carotid nerve were excluded from further analysis in both axotomized and control ganglia. Processes other than the axon and axon collaterals were considered to be dendrites. In most of the neurons that met the above criteria, the HRP reaction 
A. Normal
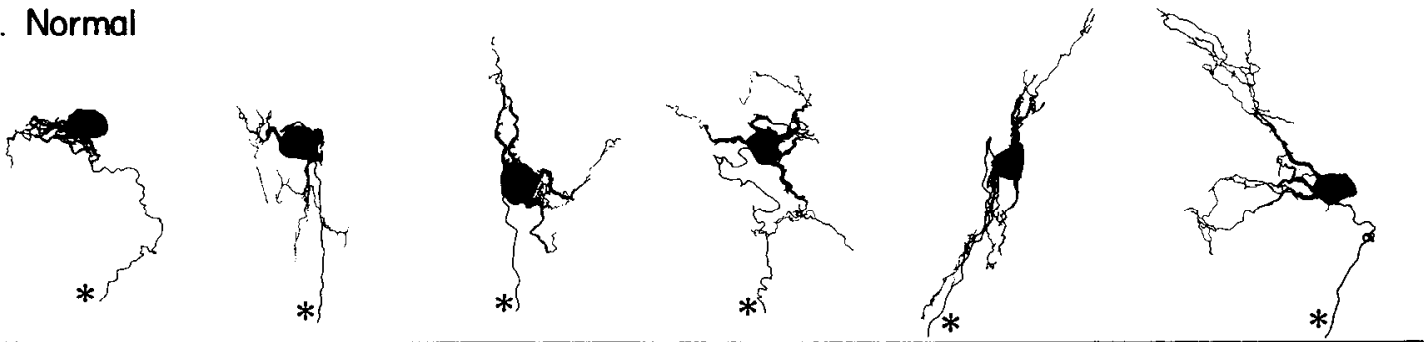

B. Axotomized, I wk.
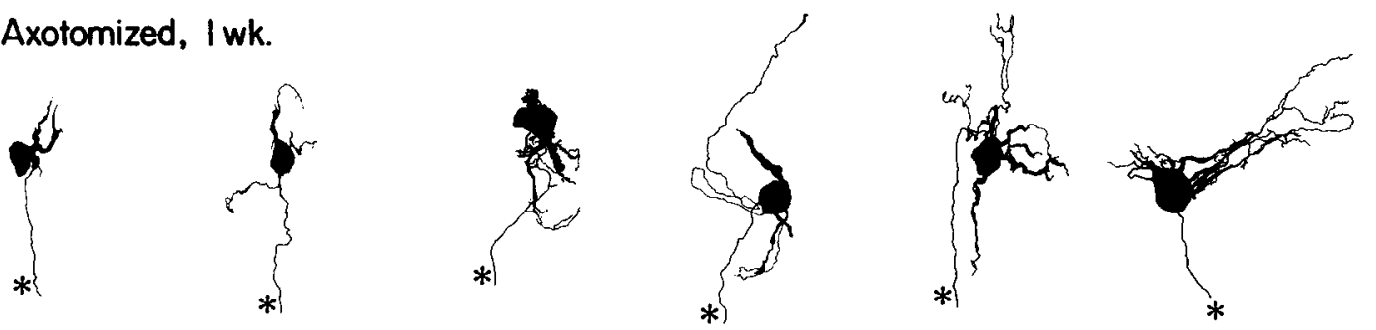

C. Axotomized, 2 wks.
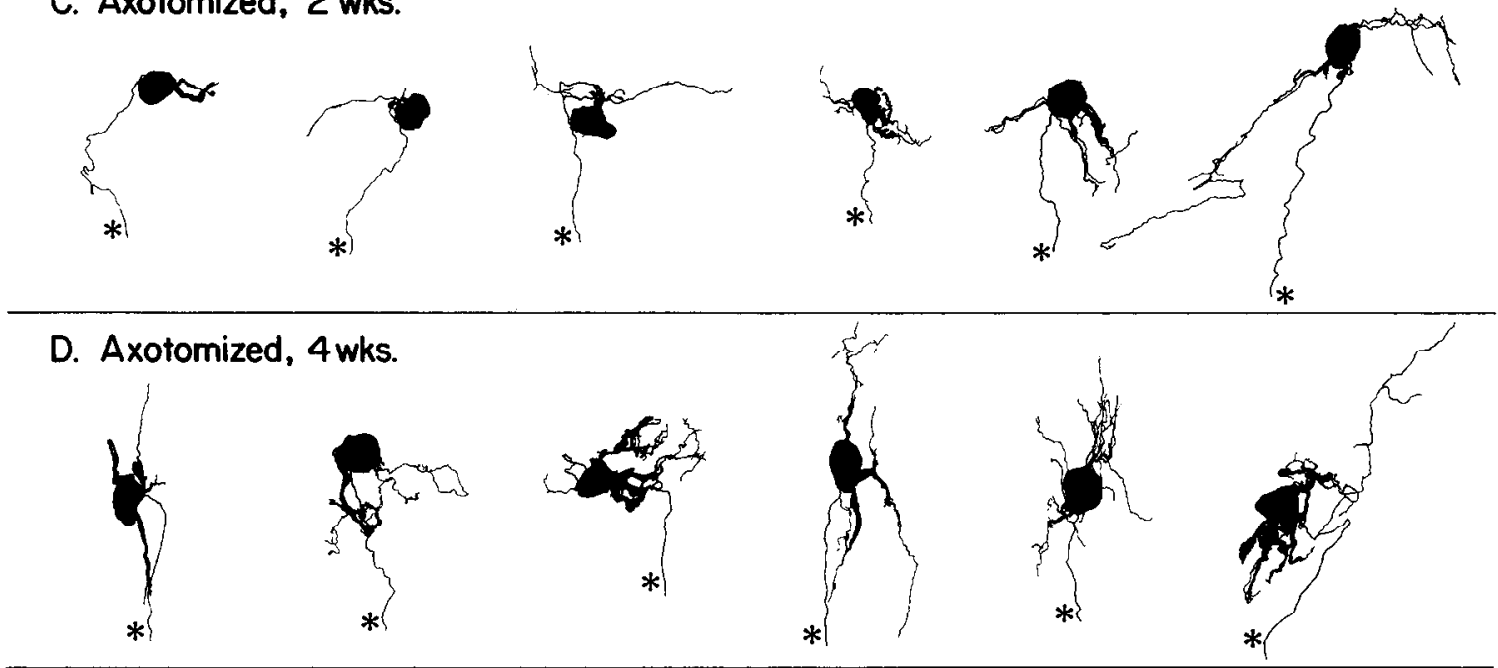

E. Axotomized, 12wks.
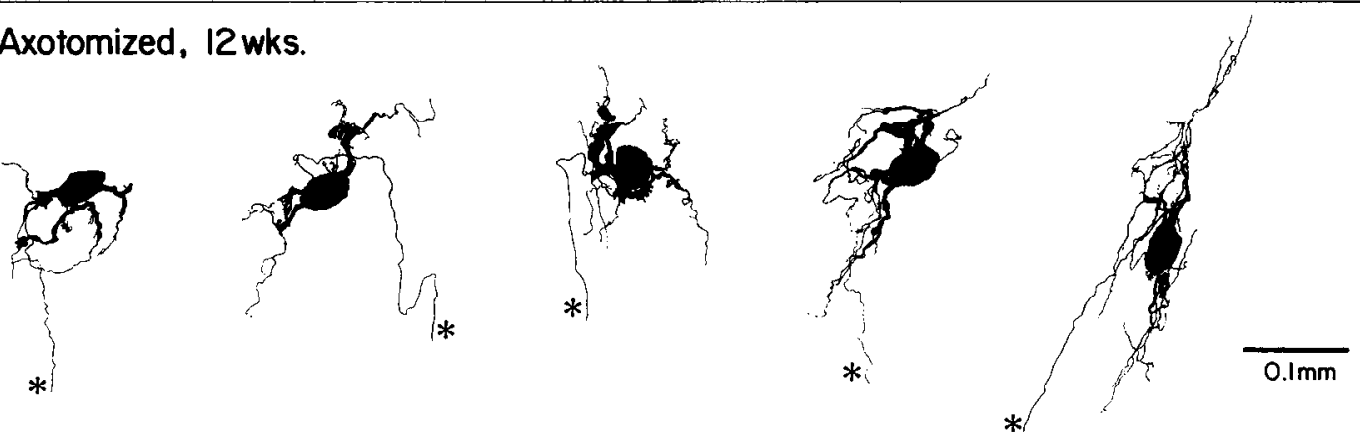

Figure 1. Neuronal geometry of representative superior cervical ganglion cells before and after axonal interruption. Cells were chosen to represent the full range of total dendritic lengths at each time point (see Fig. 2). Postganglionic axons are indicated with an asterisk.

product could be followed with a $50 \times$ water-immersion objective (nominal aperture, 1.00) out to the tip of each dendritic process. The dendritic geometry of labeled neurons was traced using a camera lucida drawing tube; detailed measurements were made with a digitizing tablet and a computer (see Voyvodic, 1986, 1987).

Several measurements were used to evaluate the geometry of the HRP-filled neurons. These included (1) the number of primary dendrites (a primary dendrite was defined as a process other than the axon that extended radially from the cell body for a distance at least equivalent to a cell diameter); (2) the number of dendritic branches crossing a circle centered on the cell body with a radius of half the distance from the center to the farthest extent of the dendritic arbor; (3) the total length of a neuron's dendrites; and (4) the cell body size (as measured by the cross-sectional area). There was no obvious difference in any of these measurements between right and left ganglia in control animals. Therefore the data obtained from both sides were pooled. In order to determine the statistical significance of various measurements, the 2-tailed Student's $t$ test was employed for means, and the chi-square test for medians.

Finally, the density of peripheral innervation arising from the external carotid nerve was estimated by catecholamine histofluorescence in the submandibular salivary gland (one of the major targets of the crushed nerve). In order to make this assessment, submandibular glands from both sides were removed and immediately frozen in isopentane that 


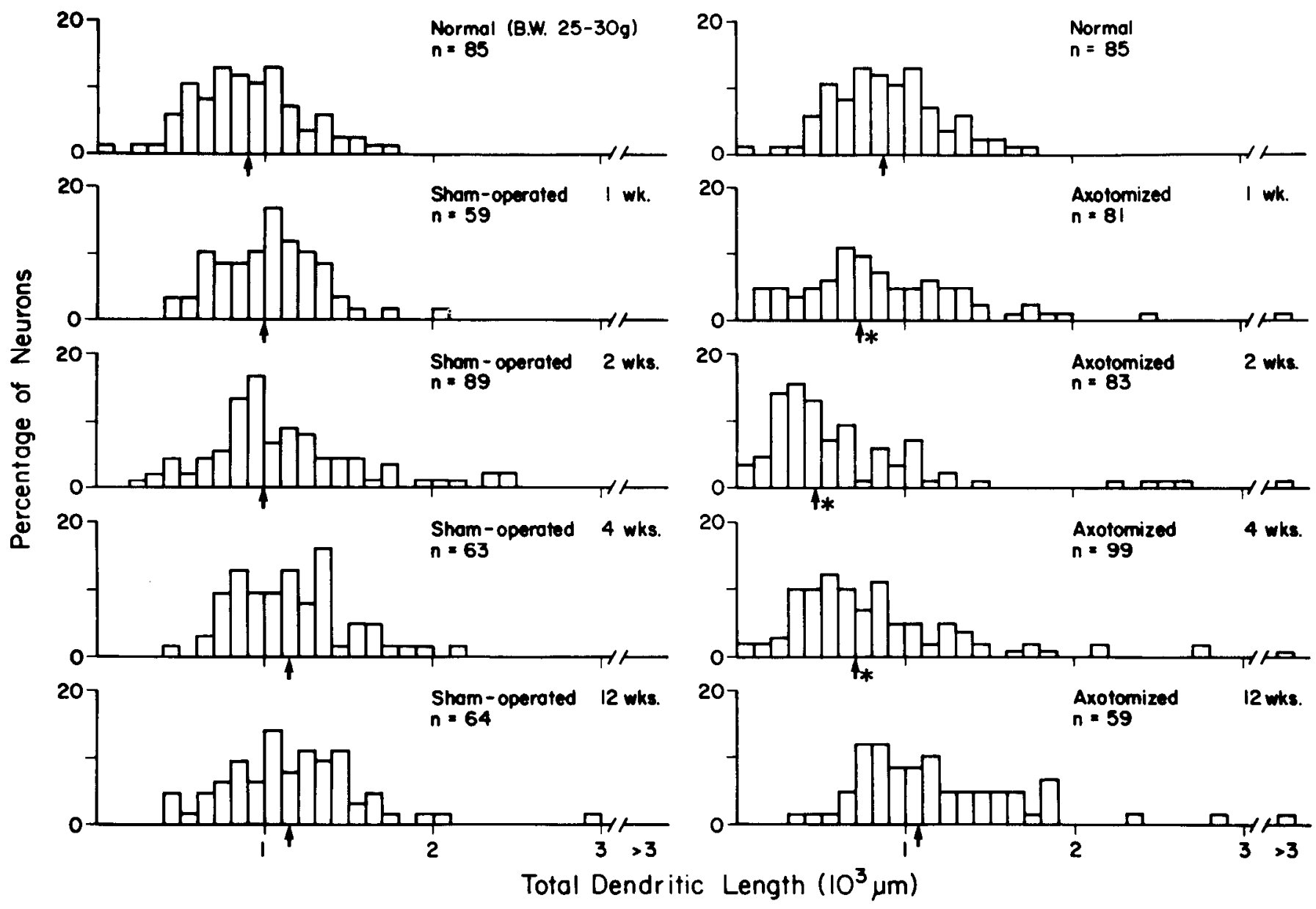

Figure 2. The distribution of total dendritic lengths among axotomized superior cervical ganglion cells (right) compared to sham-operated controls (left). Each group comprises 60-100 cells (from 5-20 animals; see Table 1). The uppermost graphs, left and right, show the distributions of the same set of normal ganglion cells. In axotomized populations, the distributions are skewed towards lower values: this effect appears to be maximal in 2 weeks. Neurons with extraordinarily lengthy arbors after axotomy were those that possessed very long neurotic processes thought to represent newly formed sprouts (see text and Fig. 4). Complete recovery appears to occur by 12 weeks after the operation. Arrows indicate medians (which are considered to represent differences better than means in such skewed distributions). Asterisks indicate that the difference between axotomized and control groups is statistically significant ( $p<0.001$; chi-square test).

had been cooled by liquid nitrogen. Within a week after storage at $-70^{\circ} \mathrm{C}, 16 \mu \mathrm{m}$ sections were prepared using a cryostat $\left(-20^{\circ} \mathrm{C}\right)$. Tissue slices were reacted according to the glyoxylic acid method of de la Torre and Surgeon (1976; see also Cottle et al., 1985). Catecholamine fluorescence was observed using a conventional epifluorescence system (Leitz D cube).

\section{Results}

Morphological changes of dendritic arbors after postganglionic axotomy

Within a week after postganglionic axotomy, some neurons whose axons could be followed into the crushed nerve showed a reduction in the extent of dendritic arbors as compared to unaxotomized control neurons in normal animals. By the end of 2 weeks, virtually all cells whose axons had been interrupted appeared to have lost a substantial portion of their dendritic arbors. Documentation for these and subsequent time points is presented in Figures 1 and 2 and Table 1. As might be expected, a net increase of dendritic length was observed during this period both among control ganglion cells of the sham-operated animals and among ganglion cells in the contralateral unaxotomized ganglia. This increase presumably arises as a result of normal dendritic growth after maturation (see Voyvodic, 1987). Subsequent to the first 2 weeks after postganglionic nerve crush, the total dendritic length of the affected ganglion cells showed gradual recovery and attained control levels by 3 months. Judging from a shift in the median (or the mode) of total dendritic length distributions (Fig. 2, right histograms), the reduced dendritic length cannot be attributed solely to the prevention of normal growth by axotomy.

By the end of 2 weeks, there was also a significant reduction in the number of dendritic branches crossing a circle drawn halfway between the somal center and the farthest extent of the dendritic arbor (Table 1). This effect paralleled the changes in dendritic length, and also regained control levels by 3 months. Figure 3 summarizes the time course of several geometrical parameters over the first 3 months after axotomy. A slight rebound in the number of primary dendrites was observed 12 weeks after axotomy, but this rather minor effect could easily be a consequence of incomplete recovery of cell body size (recall that a primary dendrite is defined here by a length greater than the cell body diameter). To test the possibility that a reduction in total dendritic length could reflect the reduced number of 
Table 1. Measurements of neuronal geometry among mouse superior cervical ganglion cells after postganglionic axotomy

\begin{tabular}{|c|c|c|c|c|c|c|c|}
\hline & $\begin{array}{l}\text { No. of } \\
\text { animals }\end{array}$ & $\begin{array}{l}\text { Animal } \\
\text { size } \\
(\mathrm{gm})\end{array}$ & $\begin{array}{l}\text { No. of } \\
\text { cells }\end{array}$ & $\begin{array}{l}\text { Total dendritic length } \\
(\mu \mathrm{m})\end{array}$ & $\begin{array}{l}\text { No. of branches } \\
\text { crossing } 50 \% \\
\text { circle }\end{array}$ & $\begin{array}{l}\text { No. of primary } \\
\text { dendrites }\end{array}$ & $\begin{array}{l}\text { Cell body size } \\
\left(\mu \mathrm{m}^{2}\right)\end{array}$ \\
\hline Normal & 11 & 27.5 & 85 & $895.9 \pm 35.4$ & $6.6 \pm 0.38$ & $3.5 \pm 0.18$ & $895.0 \pm 22.4$ \\
\hline 1 week & 5 & 30.4 & 59 & $1020.9 \pm 40.3$ & $6.8 \pm 0.42$ & $4.0 \pm 0.20$ & $1031.7 \pm 20.5$ \\
\hline 2 weeks & 6 & 33.3 & 89 & $1114.1 \pm 49.9$ & $8.2 \pm 0.45$ & $3.9 \pm 0.17$ & $1113.3 \pm 20.6$ \\
\hline 4 weeks & 6 & 36.3 & 63 & $1148.3 \pm 42.0$ & $8.5 \pm 0.58$ & $3.6 \pm 0.17$ & $1195.2 \pm 27.7$ \\
\hline 1 week & 20 & 29.4 & 81 & $845.3 \pm 72.1$ & $6.5 \pm 0.51$ & $3.4 \pm 0.18$ & $787.1 \pm 30.0^{* 4 * * *}$ \\
\hline 2 weeks & 19 & 31.1 & 83 & $694.2 \pm 69.2^{* * * *}$ & $5.5 \pm 0.22^{* * * *}$ & $2.8 \pm 0.16^{* . * *}$ & $815.5 \pm 27.2^{* * * *}$ \\
\hline 4 weeks & 16 & 32.6 & 99 & $847.8 \pm 57.1^{*}$ & $5.6 \pm 0.36^{*}$ & $3.1 \pm 0.14$ & $1051.1 \pm 25.2^{* * * *}$ \\
\hline 12 weeks & 11 & 38.1 & 59 & $1194.7 \pm 68.6$ & $8.4 \pm 0.71$ & $4.3 \pm 0.24^{*}$ & $1140.1 \pm 28.6^{*}$ \\
\hline \multicolumn{8}{|l|}{ Contralateral } \\
\hline
\end{tabular}

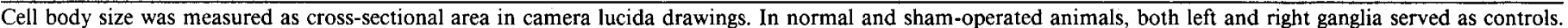
The values are given as means ( \pm SEMs).

${ }^{*} p<0.001$ (2-tailed $t$ test) vs. sham-operated control group.

${ }^{* *} p<0.001$ (2-tailed $t$ test) vs. contralateral group.

primary dendrites after axotomy (Table 1, Fig. 3), the dendritic length per primary dendrite was calculated as the total dendritic length divided by the number of primary dendrites. The distributions of dendritic length per primary dendrite were essentially similar to the distributions of total dendritic length (see Fig. 2), and the median was again significantly reduced by axotomy $(185.5 \mu \mathrm{m} 2$ weeks after axotomy and $291.3 \mu \mathrm{m} 2$ weeks after sham operation; $p<0.001$ ). Therefore, the reduction in total dendritic length of axotomized ganglion cells is not due to

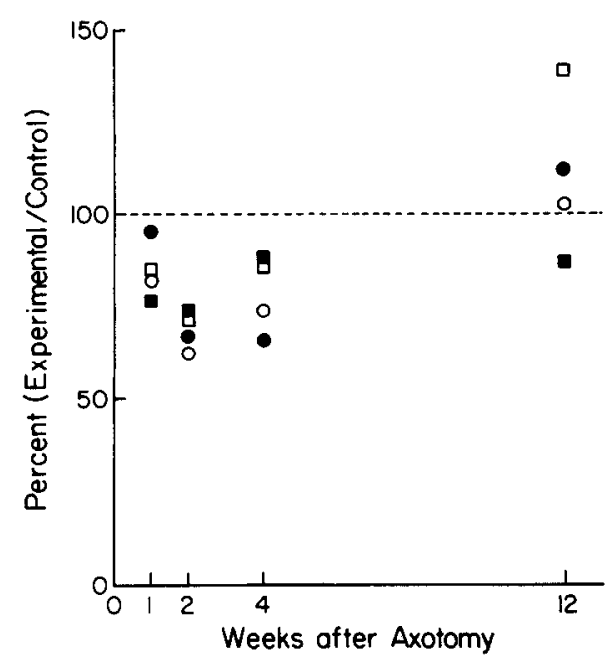

Figure 3. Graphic summary of the time course of changes in the geometry of superior cervical ganglion cells after axotomy. Total dendritic length, open circles; number of branches crossing a $50 \%$ circle, closed circles; number of primary dendrites, open squares; cell body size, closed squares. Values are expressed as percentages (mean experimental value/ mean control value). Each of these 4 measurements was reduced to about $60-70 \%$ of control values by 2 weeks after axotomy, and then recovered gradually. the reduced number of primary dendrites. In fact, the slight reduction in the number of primary dendrites of axotomized cells may be a result of diminished dendritic length.

In the early period after postganglionic axotomy (1-4 weeks), other dendrite abnormalities were also observed. The most obvious of these were varicose or clublike structures along and/or at the ends of processes, many of which were abnormally fine and long (Fig. $4 A$; see also Fig. 1). In some cells, these fine processes arose directly from the cell bodies, although most arose from more typical-looking dendrites. Occasionally, such processes entwined or terminated on what appeared to be other ganglion cell bodies (Fig. 4B). Again, the occurrence of these abnormalities was maximal at about 2 weeks and dissipated thereafter. After 3 months, very few cells with these characteristics could be found.

In addition to effects on dendritic length and complexity, measurements of the cell body indicated that the normal increase in somal size that occurs during this period was also curtailed by axotomy (see Table 1). As in the case of dendrites, this deficiency tended to disappear over several weeks, although the cell body size was still smaller than that of controls at the end of 3 months. There was no apparent correlation between cell body size and total dendritic length in any of the populations of control or axotomized ganglion cells. Therefore, these 2 parameters evidently represent independent facets of the morphological differentiation of ganglion cells.

\section{Peripheral innervation after axotomy}

Catecholamine histofluorescence was examined in the submandibular salivary gland, a major target of the crushed postganglionic nerve. In control salivary glands (including glands contralateral to operated ganglia), catecholaminergic nerve terminals were abundant throughout the substance of the gland (Fig. 5A). However, catecholamine histofluorescence in the glands on the operated side was markedly reduced within a week of postgan- 

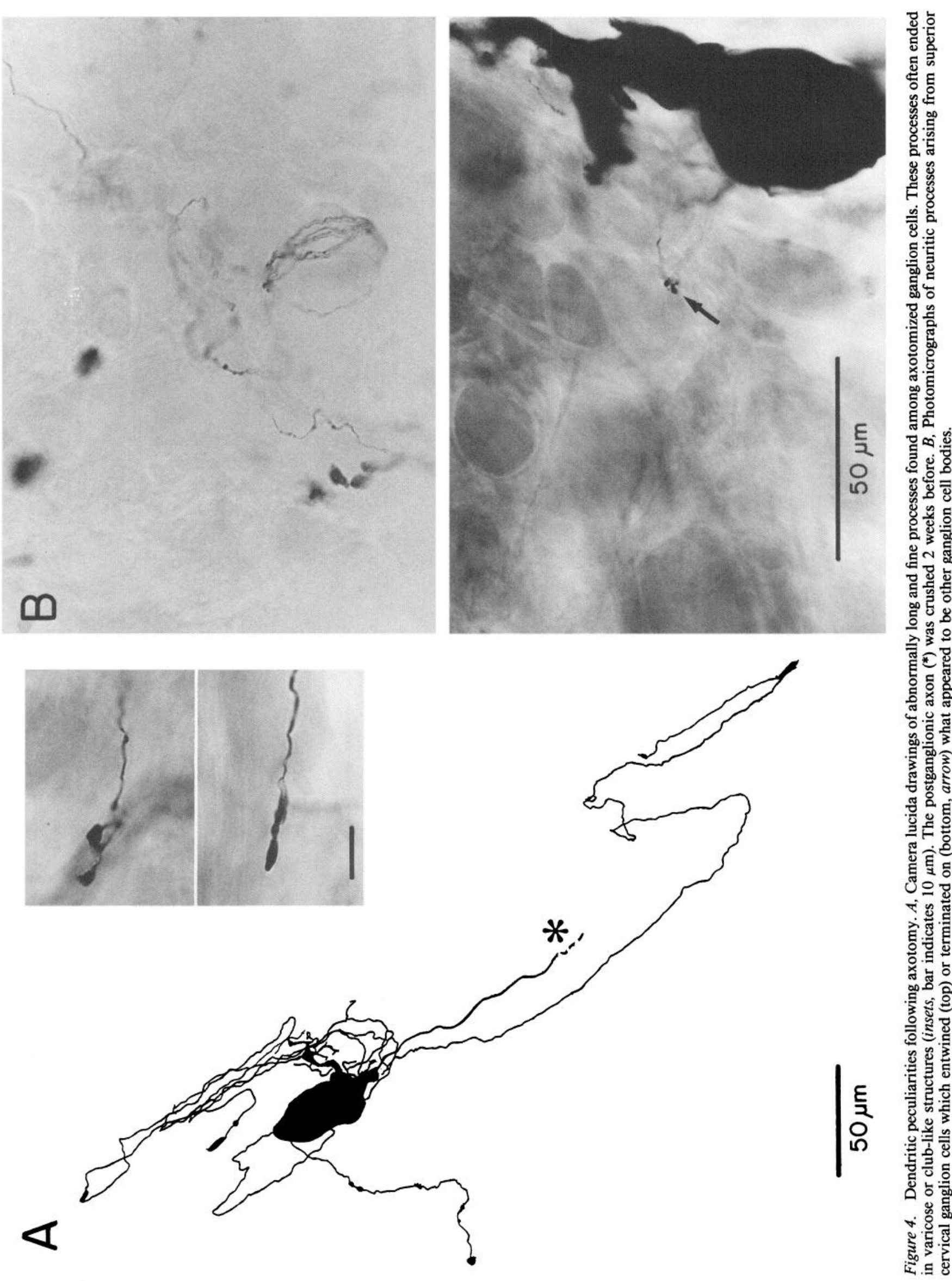

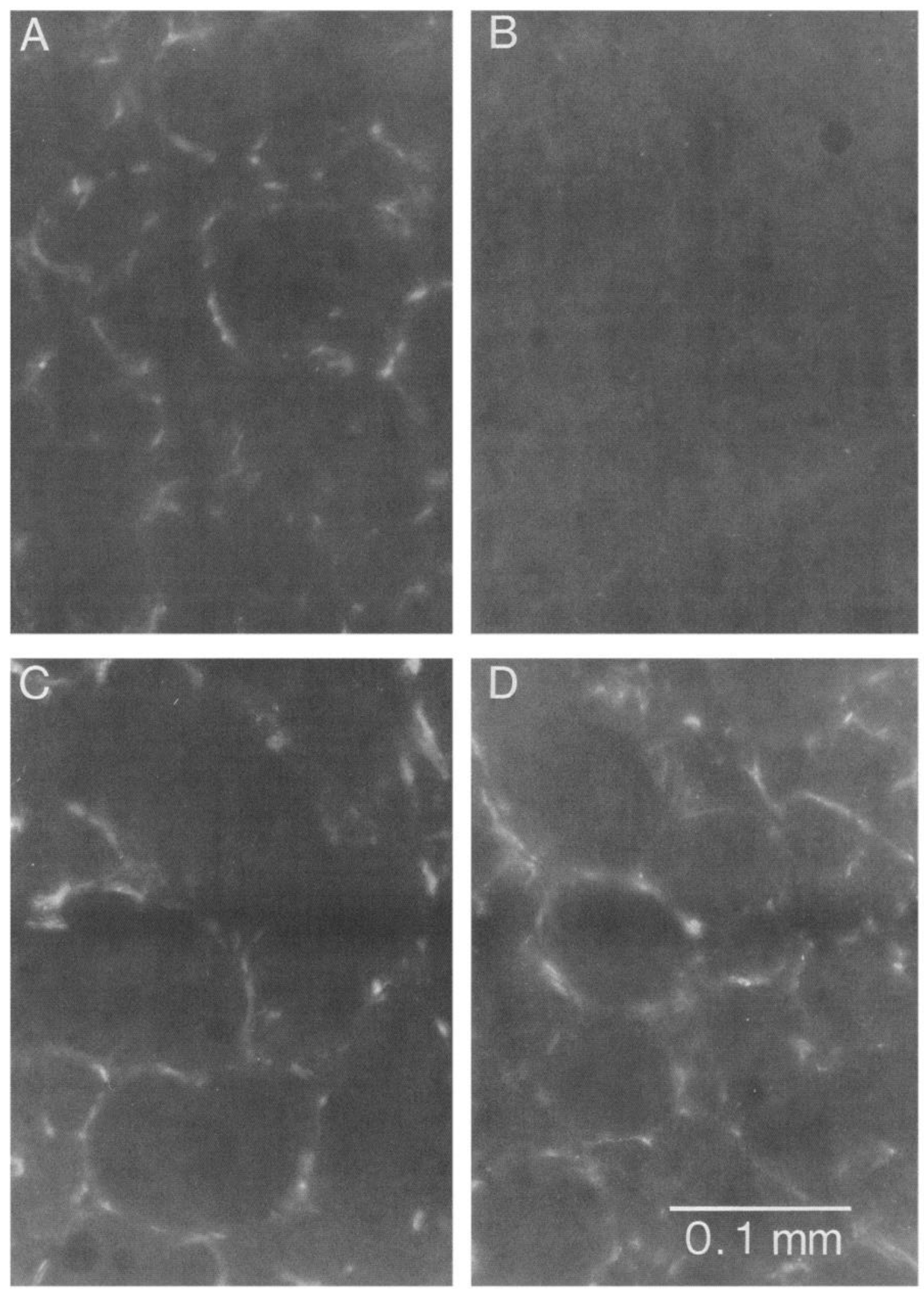

Figure 5. Catecholamine histofluorescence in frozen sections of the submandibular salivary glands. Upper panels, Catecholamine fluorescence in the submandibular glands from the contralateral control $(A)$ and the operated side $(B)$ of an animal 1 week after crushing of its external carotid nerves. There are abundant catecholaminergic nerve terminals throughout the substance of the control side $(A)$, whereas there is no detectable catecholamine fluorescence in the glands whose nerve was crushed a week earlier. Lower panels, Catecholamine fluorescence of the submandibular glands from the contralateral control $(C)$ and axotomized side $(D)$ of an animal 12 weeks after crushing one of its external carotid nerves. The density of catecholaminergic innervation on the 2 sides is now similar, indicating full reinnervation by the crushed nerve. 
glionic nerve crush (Fig. 5B). By 1-2 weeks after axotomy, fluorescence was observed only in the immediate vicinity of blood vessels in the affected salivary glands. Four weeks after axotomy, the density of catecholaminergic nerves in the affected submandibular gland had increased, although it remained lower than control. Three months after axotomy, the density of catecholamine histofluorescence appeared to be roughly normal (Fig. $5, C, D)$, implying full recovery of peripheral innervation. It might be argued that the submandibular gland could be reinnervated by the contralateral, intact ganglion rather than by the axotomized one. To test this, the contralateral external carotid nerve was crushed 1 week before examination of the catecholamine fluorescence of the submandibular gland. In this case, full recovery of catecholamine fluorescence was again observed 12 weeks after crushing the nerve. Therefore, the contralateral external carotid nerve did not provide significant innervation to the denervated salivary glands.

\section{Discussion}

The results reported here indicate that the dendritic arbors of superior cervical ganglion cells react to postganglionic axotomy with a transient involution of their dendritic arbors. This effect reaches a maximum in about 2 weeks, and recovers in parallel with reinnervation of peripheral targets. Although, to my knowledge, no similar quantitative studies of the dendritic reaction to axotomy have been made using intracellular injection of a marker, a number of observations made with other techniques are consistent with the present findings. Thus, in the rat hypoglossal nucleus examined after Golgi impregnation, dendritic arbors were decreased a few weeks after axotomy, and tended to re-expand thereafter (Sumner and Watson, 1971). Reduction of the dendritic fields of spinal motoneurons was also demonstrated with Golgi staining after ventral root transection (Cerf and Chacko, 1958; Standler and Bernstein, 1982). A small number of intracellularly injected ganglion cells in the guinea pig also showed an obvious reaction following axotomy that suggested altered growth of dendritic processes (Purves, 1975). Electron-microscopic observation of axotomized ganglia showed dendritic swellings with organelles similar to those found in growth cones (Matthews and Nelson, 1975; Purves, 1975, 1976).

Taken together, these results suggest that the integrity of postganglionic axons is important in the morphological maintenance of dendritic arbors. One possibility, of course, is that the reaction I observed was simply a result of neuronal damage. Although this is difficult to rule out, numerous studies of other aspects of the axotomy reaction - metabolic changes and the synapse loss known to follow axonal interruption - have indicated that these changes are not due to injury per se (Sumner and Watson, 1971; Pilar and Landmesser, 1972; Watson, 1974; Purves, 1976).

The most conventional explanation of other axotomy-induced changes is loss of trophic support from the periphery (Cragg, 1970; Lieberman, 1971; Kuno et al., 1974; Purves, 1975, 1976; Mendell et al., 1976). For sympathetic neurons, the protein NGF appears to play an important part in this regulation (Hendry, 1975; Purves and Njå, 1976; Njå and Purves, 1978; see also Purves and Lichtman, 1978; Purves and Njå, 1978; Levi-Montalcini and Aloe, 1983; Thoenen and Edgar, 1985). Although I have no direct evidence, a similar explanation is equally plausible in the case of dendritic maintenance. In this view, the loss of dendritic length and complexity within 2 weeks of axotomy arises because of a diminished trophic signal from the periphery; as the axon regenerates and regains a portion of its initial trophic support, the dendritic arbor expands accordingly. A similar scenario has been suggested for normal development (see Jacobson, 1978). For example, in several systems, including rat superior cervical ganglia, axonal extension to targets precedes the growth and differentiation of dendrites (Hamburger and Keefe, 1944; Barron, 1948; Hinds and Hinds, 1976; Wise et al., 1979; Rubin, 1985; see, however, Landmesser and Pilar, 1974; Hughes and LaVelle, 1975; Oppenheim et al., 1978). Further evidence that supports this general view is that exogenous administration of NGF to neonatal rats enhances the complexity and length of dendritic arborizations and the rate of dendritic growth in the superior cervical ganglion (Snider, 1986, and unpublished observations).

It should be noted, however, that afferents do affect dendritic geometry in some parts of the nervous system, such as neurons in chick auditory nuclei (Levi-Montalcini, 1949; Benes et al., 1977; Deitch and Rubel, 1984) and cerebellar Purkinje cells (Rakic and Sidman, 1973). In some neuronal systems, removal of afferent inputs curtails the very survival of postsynaptic cells in the course of normal development (Oppenheim, 1981; Okado and Oppenheim, 1984; Clarke, 1985). Nevertheless, the absence of afferent input has little influence on the dendritic differentiation of spinal neurons (Brown et al., 1983; Sedivec et al., 1986; see, however, Brown et al., 1979) or of sympathetic ganglion cells (Hamlyn, 1954; McLachlan, 1974; Smolen and BeastonWimmer, 1986; Voyvodic, 1987) (although afferent input is necessary for the biochemical differentiation of sympathetic ganglion cells; see Black, 1978, 1982). Therefore, it is quite unlikely that axotomy of the superior cervical ganglion first induces a loss of afferent synapses, which then results in a secondary dendritic atrophy.

One aspect of the present observations that is not easily rationalized is the presence on some axotomized cells of fine processes that appear to be elongating rather than retracting (see Matthews and Nelson, 1975; Purves, 1975). Dendritic sprouting has also been reported in lamprey hindbrain neurons when the axons are transected close to the cell bodies (Hall and Cohen, 1983), and chronically axotomized cat spinal motoneurons respond to axotomy by developing supernumerary axons (Havton and Kellerth, 1987). A possible explanation is suggested by the fact that neurons in parasympathetic ganglia respond to local denervation by sprouting (Sargent and Dennis, 1981; D. A. Johnson, unpublished observations). Perhaps the cholinergic population of superior cervical ganglion cells (thought to bc about 5\%; see Sjöqvist, 1963a,b; Buckley et al., 1967; Yamauchi et al., 1973) reacts in a manner similar to the preganglionic synapse loss that follows axotomy (Matthews and Nelson, 1975; Purves, 1975).

In conclusion, one of the factors that appears to determine the configuration of neuronal dendrites among autonomic neurons is the integrity of postganglionic axons and, presumably, their interaction with peripheral targets. An influence of this sort would allow neurons to adjust their form, and thus the innervation they receive, in concert with the extent of their innervation of target cells. Such retrograde influence may also be relevant to the ongoing growth and retraction of dendrites recently observed among the superior cervical ganglion cells of adult mice (Purves and Hadley, 1985; Purves et al., 1986), and to the overall increase in the size of dendritic arbors that parallels the continued growth of rodents in maturity (Voyvodic, 1987). 


\section{References}

Barron, D. H. (1948) Some effects of amputation of the chick wing bud on the early differentiation of the motor neuroblasts in the associated segments of the spinal cord. J. Comp. Neurol. 88: 93-127.

Benes, F. M., T. N. Parks, and E. W. Rubel (1977) Rapid dendritic atrophy following deafferentation: An EM morphometric analysis. Brain Res. 122: 1-13.

Black, I. B. (1978) Regulation of autonomic development. Annu. Rev. Neurosci. 1: 183-214.

Black, !. B. (1982) Stages of neurotransmitter development in autonomic neurons. Science 215: 1198-1204.

Brown, A. G., P. B. Brown, R. E. W. Fyffe, and L. M. Pubols (1983) Effects of dorsal root section on spinocervical tract neurones in the cat. J. Physiol. (Lond.) 337: 589-680.

Brown, P. B., G. K. Busch, and J. Whittington (1979) Anatomical changes in cat dorsal horn cells after transection of a single dorsal root. Exp. Neurol. 64: 453-468.

Buckley, G., S. Consolo, E. Giacobini, and F. Sjöqvist (1967) Cholineacetylase in innervated and denervated sympathetic ganglia and ganglion cells of the cat. Acta Physiol. Scand. 71: 348-356.

Cerf, J. A., and L. W. Chacko (1958) Retrograde reaction in motoneuron dendrites following ventral root section in the frog. J. Comp. Neurol. 109: 205-216.

Clarke, P. G. H. (1985) Neuronal death during development in the isthmo-optic nucleus of the chick: Sustaining role of afferents from the tectum. J. Comp. Neurol. 234: 365-379.

Cottle, M. K. W., W. H. Cottle, F. Pérusse, and L. J. Bukowiecki (1985) An improved glyoxylic acid technique for the histochemical localization of catecholamines in brown adipose tissue. Histochem. J. 17: 1279-1288.

Cragg, B. G. (1970) What is the signal for chromatolysis? Brain Res. 23: $1-21$.

Deitch, J. S., and E. W. Rubel (1984) Afferent influences on brainstem auditory nuclei of the chicken; time course and specificity of dendritic atrophy following deafferentation. J. Comp. Neurol. 229: 66-79.

de la Torre, J. C., and J. W. Surgeon (1976) A methodological approach to rapid and sensitive monoamine histofluorescence using a modified glyoxylic acid technique; the SPG method. Histochemistry 49: 8193.

Forehand, C. J., and D. Purves (1984) Regional innervation of rabbit ciliary ganglion cells by the terminals of preganglionic axons. J. Neurosci. 4: $1-12$.

Hall, G. F., and M. J. Cohen (1983) Extensive dendritic sprouting induced by close axotomy of central neurons in the lamprey. Science 222: 518-521.

Hamburger, V., and E. L. Keefe (1944) The effects of peripheral factors on the proliferation and differentiation of the spinal cord of chick embryos. J. Exp. Zool. 96: 223-242.

Hamlyn, L. H. (1954) The effect of preganglionic section on the neurons of the superior cervical ganglion in rabbits. J. Ana*: 88: 184191.

Hanker, J. S., P. E. Yates, C. B. Metz, and A. Rustioni (1977) A new specific, sensitive and non-carcinogenic reagent for the demonstration of horscradish peroxidasc. Histochem. J. 9: 789-792.

Havion, L., and J.-O. Kellerth (1987) Regeneration by supernumerary axons with synaptic terminals in spinal motoneurons of cats. Nature 325: 711-714.

Hendry, I. A. (1975) Response of adrenergic neurones to axotomy and nerve growth factor. Brain Res. 94: 87-97.

Hinds, J. W., and P. L. Hinds (1976) Synapse formation in the mouse olfactory bulb. I. Quantitative studies. J. Comp. Neurol. 169: 15-40.

Hughes, W. F., and A. LaVelle (1975) The effects of early tectal lesions on development in the retinal ganglion cell layer of chick embryos. J. Comp. Neurol. 163: 265-283.

Hume, R. I., and D. Purves (1981) Geometry of neonatal neurones and the regulation of synapse elimination. Nature 293: 469-471.

Jacobson, M. (1978) Developmental Neurobiology, Plenum, New York.

Kuno, M., Y. Miyata, and E. J. Muñoz-Martinèz (1974) Properties of fast and slow alpha motoneurones following motor reinnervation. $J$. Physiol. (Lond.) 242: 273-288.

Landmesser, L., and G. Pilar (1974) Synapse formation during embryogenesis on ganglion cells lacking a periphery. J. Physiol. (Lond.) 241: 715-736.

Levi-Montalcini, R. (1949) The development of the acoustico-vestibu- lar centers in the chick embryo in the absence of the afferent root fibers and descending fiber tracts. J. Comp. Neurol. 91: 209-242.

Levi-Montalcini, R., and L. Aloe (1983) The effect of nerve growth factor on autonomic ganglion cells. In Autonomic Ganglia, L.-G. Elfvin, ed., pp. 401-426, Wiley, Chichester, UK.

Lieberman, A. R. (1971) The axon reaction: A review of the principal features of perikaryal responses to axon injury. In International Review of Neurobiology, C. C. Pfeiffer and J. R. Smythies, eds., pp. 49124, Academic, New York.

Matthews, M. R., and V. H. Nelson (1975) Detachment of structurally intact nerve endings from chromatolytic neurones of rat superior cervical ganglion during the depression of synaptic transmission induced by postganglionic axotomy. J. Physiol. (Lond.) 245: 91-136.

McLachlan, E. M. (1974) The formation of synapses in mammalian sympathetic ganglia reinnervated with preganglionic or somatic nerves. J. Physiol. (Lond.) $23 \%: 217-242$.

Mendell, L. M., J. B. Munson, and J. G. Scott (1976) Alternation of synapses on axotomized motoneurons. J. Physiol. (Lond.) 255: 6769.

Njå, A., and D. Purves (1978) The effects of nerve growth factor and its antiserum on synapses in the superior cervical ganglion of the guinea-pig. J. Physiol. (Lond.) 277: 53-75.

Okado, N., and R. W. Oppenheim (1984) Cell death of motoneurons in the chick embryo spinal cord. IX. The loss of motoneurons following removal of afferent inputs. J. Neurosci. 4: 1639-1652.

Oppenheim, R. W. (1981) Neuronal cell death and some related regressive phenomena during neurogenesis: A selective historical review and a progress report. In Studies in Developmental Neurobiology: Essays in Honor of Viktor Hamburger, W. M. Cowan, ed., pp. 74133, Oxford U. P., New York.

Oppenheim, R. W., I.-W. Chu-Wang, and J. L. Maderdrut (1978) Cell death of motoneurons in the chick embryo spinal cord. III. The differentiation of motoneurons prior to their induced degeneration following limb-bud removal. J. Comp. Neurol. 177: 87-112.

Pilar, G., and L. Landmesser (1972) Axotomy mimicked by localized colchicine application. Science 171: 1116-1118.

Purves, D. (1975) Functional and structural changes in mammalian sympathetic neurones following interruptions of their axons. J. Physiol. (Lond.) 252: 429-463.

Purves, D. (1976) Functional and structural changes in mammalian sympathetic neurones following colchicine application to postganglionic nerves. J. Physiol. (Lond.) 259: 159-175.

Purves, D., and R. D. Hadley (1985) Changes in the dendritic branching of adult mammalian neurones. Nature 315:404-406.

Purves, D., and R. I. Hume (1981) The relation of postsynaptic geometry to the number of presynaptic axons that innervate autonomic ganglion cells. J. Neurosci. 1 : 441-452.

Purves, D., and J. W. Lichtman (1978) Formation and maintenance of connections in autonomic ganglia. Physiol. Rev. 58: 821-862.

Purves, D., and J. W. Lichtman (1985) Geometrical differences among homologous neurons in mammals. Science 228: 298-302.

Purves, D., and A. Njå (1976) Effect of nerve growth factor on synaptic depression after axotomy. Nature 260: 533-536.

Purves, D., and A. Njå (1978) Trophic maintenance of synaptic connections in autonomic ganglia. In Neuronal Plasticity, C. W. Cotman, ed., pp. 27-47, Raven, New York.

Purves, D., R. D. Hadley, and J. T. Voyvodic (1986) Dynamic changes in the dendritic geometry of individual neurons visualized over periods of up to three months in the superior cervical ganglion of living mice. J. Neurosci. 6: 1051-1060.

Rakic, P., and R. L. Sidman (1973) Organization of cerebellar cortex secondary to deficit of granule cells in weaver mutant mice. J. Comp. Neurol. 152: 133-162.

Rubin, E. (1985) Development of the rat superior cervical ganglion: Ganglion cell maturation. J. Neurosci. 5: 673-684.

Sargent, P. B., and M. J. Dennis (1981) The influence of normal innervation upon abnormal synaptic connections between frog parasympathetic neurons. Dev. Biol. 81: 65-73.

Sedivec, M. J., J. J. Capowski, and L. M. Mendell (1986) Morphology of HRP-injected spinocervical tract neurons: Effect of dorsal rhizotomy. J. Neurosci. 6: 661-672.

Sjöqvist, F. (1963a) The correlation between the occurrence and localization of acetylcholinesterase-rich cell bodies in the stellate ganglion and the outflow of cholinergic sweat secretory fibres to the fore paw of the cat. Acta Physiol. Scand. 57: 339-351. 
Sjöqvist, F. (1963b) Pharmacological analysis of acetylcholinesteraserich ganglion cells in the lumbo-sacral sympathetic system of the cat. Acta Physiol. Scand. 57: 352-362.

Smolen, A. J., and P. Beaston-Wimmer (1986) Dendritic development in the rat superior cervical ganglion. Dev. Brain Res. 29: 245-252.

Snider, W. D. (1986) The effect of nerve growth factor on the development of dendritic arbors in the rat superior cervical ganglion. Soc. Neurosci. Abstr. 12: 1098.

Standler, N. A., and J. J. Bernstein (1982) Degeneration and regeneration of motoneuron dendrites after ventral root crush: Computer reconstruction of dendritic fields. Exp. Neurol. 75: 600-615.

Sumner, B. E. H., and W. E. Watson (1971) Retraction and expansion of the dendritic tree of motor neurones of adult rats induced in vivo. Nature 233: 273-275.

Thoenen, H., and D. Edgar (1985) Neurotrophic factors. Science 229: $238-242$.

Voyvodic, J. T. (1986) A general purpose image processing language
(IMAGR) facilitates visualizing neuronal structures in fixed tissue and in vivo. Soc. Neurosci. Abstr. 12: 390.

Voyvodic, J. T. (1987) Development and regulation of dendrites in the rat superior cervical ganglion. J. Neurosci. 7: 904-912.

Watson, W. E. (1974) Cellular responses to axotomy and to related procedures. Br. Med. Bull. 30: 112-115.

Wise, S. P., J. W. Fleshman, Jr., and E. G. Jones (1979) Maturation of pyramidal cell form in relation to developing afferent and efferent connections of rat somatic sensory cortex. Neuroscience 4: 12751297.

Yamauchi, A., J. D. Lever, and K. W. Kemp (1973) Catecholamine loading and depletion in the rat superior cervical ganglion: A formal fluorescence and enzyme histochemical study with numerical assessments. J. Anat. 114: 271-282.

Yawo, H. (1986) Geometrical changes of mouse sympathetic ganglion cells after axotomy. Soc. Neurosci. Abstr. 12: 1105. 